\begin{tabular}{|c|c|}
\hline & $\begin{array}{l}\text { International Journal of Trend in Scientific } \\
\text { Research and Development (IJTSRD) }\end{array}$ \\
\hline 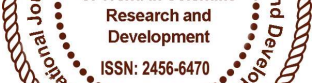 & International Open Access Journal \\
\hline 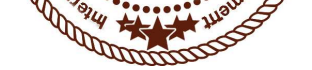 & ISSN No: 2456 - 6470 | www.ijtsrd.com | Volume - 2 | Issue - 2 \\
\hline
\end{tabular}

\title{
IND AS: India's Accounting Standards Converged with the IFRS - (IND AS Adoption and Applicability for Indian Companies)
}

\author{
N. Sharadha \\ Research scholar, Alagappa University, Karaikudi
}

\author{
Prof. V. Manickavasagam \\ Dean, Faculty of Management, \\ Alagappa University, Karaikudi
}

\section{ABSTRACT}

India made a commitment towards the convergence of Indian accounting standards with IFRS at theG20 summit in 2009. In line with this, the Ministry of Corporate Affairs, Government of India (MCA) previously issued a roadmap for implementation of Indian Accounting Standards (Ind AS) converged with International Financial Reporting Standards (IFRS) beginning April 2011. However, this plan was suspended due to unresolved tax and other issues.

In the presentation of the Union Budget 2014-15, the Honorable Minister for Finance, Corporate Affairs and Information and Broadcasting proposed the adoption of Ind AS. The Minister clarified that the respective regulators will separately notify the date of implementation for banks and insurance companies. Also, standards for tax computation would be notified separately. In accordance with the Budget statement, the MCA has notified Company (Indian Accounting Standard) Rules 2015 vide its G.S.R dated 16 February 2015. Accordingly, it has notified 39 Ind AS and has laid down an Ind AS transition road map for companies other than banking companies, insurance companies and non- banking finance companies. Though the adoption of Ind AS could create certain complexities, in the long run, this major regulatory reform will help them catapult into the global league by having a financial reporting structure that is not only comparable with the best in the world but also more acceptable amongst global stakeholders thereby providing a more transparent view of their financial results. Overall, the MCA and the Institute of Chartered Accountants of India (ICAI) swiftly worked towards drafting the new accounting framework, this 'mandate' is perceived as a step in the right direction and the industry is taking steps to keep pace with this landmark development.

Keywords: Ind AS, IFRS Convergence, Voluntary Adoption of Ind $A S$

\subsection{INTRODUCTION:}

Ind AS or Indian Accounting Standards govern the accounting and recording of financial transactions as well as the presentation of statements such as profit and loss account and balance sheet of a company. For long, there has been a heated debate about Indian companies moving to the globally accepted International Financial Reporting Standards (IFRS) for their accounts. But firms have resisted this shift, stating that this will lead too many changes in the capture and reporting of their numbers. Ind AS has been evolved as a compromise formula that tries to harmonize Indian accounting rules with the IFRS.

\subsection{NEED FOR IND AS:}

Ind AS will not just change the way companies present their numbers, but may also bump up or knock down the profits/losses of firms. Here are a few instances. Under the existing rules, incentives, discounts or rebates given to customers by a firm can be shown as part of advertising, sales promotion or marketing expenses, which figure in the costs. But under Ind AS, these will have to be deducted from sales (revenues). Excise duties which are currently 
netted off from revenues to show 'net sales', will have to be shunted under 'expenses' under Ind AS.

Intangible assets such as goodwill had to be amortized, or written off as expenses over a period of time until now. Ind AS treats such items as having an indefinite life and hence they need not be amortized. This can lift the profits of firms which carry sizeable goodwill on their books.

Ind AS advocates the 'fair value' method of accounting. For example, currently, investments by a company in government securities or mutual funds are shown at the lower of cost and fair value (market value). Under Ind AS, these will have to necessarily be captured at fair value. For firms which have legacy or under-valued investments, this revaluation can expand the balance sheet size.

The new Ind AS also promises clearer disclosures to investors in certain cases. So far companies reported their segment-wise performance based on a broad product/service grouping or even geographical segments (within India, Outside India). But Ind AS requires that segments reported to investors are the same as the firm uses for the purpose of assessing performance and allocating resources.

\subsection{NOTIFICATION OF RULES FOR IND AS IMPLEMENTATION}

Consistent with its January 2015 announcement, the Ministry of Corporate Affairs (MCA) has moved quite swiftly and notified its phase-wise roadmap for adoption of the Indian Accounting Standards (Ind AS) - India's accounting standards converged with the IFRS. After lingering skepticism regarding Ind AS getting notified, this positive development positions
India well at the center of high quality financial reporting. The MCA has issued a notification dated 16 February 2015 announcing the Companies (Indian Accounting Standards) Rules, 2015 for applicability of Ind AS.

\subsection{APPLICABILITY}

The application of Ind AS is based on the listing status and net worth of a company. Ind AS will first apply to companies with a net worth equal to or exceeding 500 crore INR beginning 1 April 2016. This will also require comparative Ind AS information for the period of 1 April 2015 to 31 March 2016. Listed companies as well as others having a net worth equal to or exceeding 250 crore INR will follow 1 April 2017 onwards. Ind AS will also apply to subsidiaries, joint ventures, associates as well as holding companies of the entities covered by the roadmap

\subsection{ADOPTION OF IND AS:}

\section{- Voluntary adoption}

Companies may voluntarily adopt Ind AS for financial statements for accounting periods beginning on or after 1 April 2015, with the comparatives for the periods ending on 31 March 2015 or thereafter. Once a company opts to follow Ind $\mathrm{AS}$, it will be required to follow the Ind AS for all the subsequent financial statements (the option is irrevocable). Once the option to voluntary follow Ind AS is adopted, companies will not be required to prepare another set of financial statements in accordance with Accounting Standards specified in Annexure to Companies (Accounting Standards) Rules, 2006.

\section{- Mandatory adoption}

The following class of companies needs to comply with the Ind AS in preparation of the financial statements:

For the accounting period beginning on or after 1 April 2016 (Phase 1)

The following companies will have to adopt Ind AS for financial statements from the above mentioned date:

$\square$ Companies whose equity or debt securities are listed or are in the process of listing on any stock exchange in India or outside India (listed companies) and having net worth of Rs.500 crores or more

\section{For the accounting period beginning on or} after 1 April 2017 (Phase 2)

The following companies will have to adopt Ind AS for financial statements from the above mentioned date:

$\square$ Listed companies having net worth of less than Rs.500 crore

$\square$ Unlisted companies having net worth of Rs.250 crore or more but less than Rs.500 crore

Holding, subsidiary, joint venture or associate 


\begin{tabular}{|l|l|}
\hline Unlisted companies having a net worth of & $\begin{array}{l}\text { companies of the listed and unlisted companies } \\
\text { covered above }\end{array}$ \\
Rs.500 crores or more \\
$\begin{array}{l}\text { Holding, subsidiary, joint venture or associate } \\
\text { companies of the listed and unlisted companies } \\
\text { covered above }\end{array}$ & \\
\hline $\begin{array}{l}\text { Comparative for these financial statements will be } \\
\text { periods ending } 31 \text { March } 2016 \text { or thereafter. }\end{array}$ & $\begin{array}{l}\text { Comparative for these financial statements will be } \\
\text { periods ending 31 March } 2017 \text { or thereafter. }\end{array}$ \\
\hline
\end{tabular}

Once a company starts following the Ind AS mandatorily on the basis of the criteria specified above, it will be required to follow the Ind AS for all the subsequent financial statements even if any of the criteria specified do not subsequently apply to it.

Companies to which Ind AS are applicable should prepare their first set of financial statements in accordance with the Ind AS effective at the end of its first Ind AS reporting period i.e., companies preparing financial statements applying the Ind AS for the accounting period beginning on 1 April 2016 should apply the Ind AS effective for the financial year ending as on 31 March 2017.

\subsection{IND AS AND IFRS AT A GLANCE}

The entities' general purpose financial statements give information about performance, position and cash flow that is useful to a range of users in making financial decisions. These users include shareholders, creditors, employees and the general public.

A complete set of financial statements under Ind AS includes the following:

- Balance sheet at the end of the period

- Statement of profit and loss for the period

- Statement of changes in equity for the period

- Statement of cash flows for the period; notes, comprising a summary of significant accounting policies and other explanatory information

- Comparative financial information in respect of the preceding period as specified

- Balance sheet as at the beginning of the preceding period when an entity applies an accounting policy retrospectively or makes a retrospective restatement of items in its financial statements, or when it reclassifies items in its financial statements having an impact on the balance sheet as at the beginning of the preceding period.

India has chosen a path of International Financial Reporting Standards (IFRS) convergence rather than adoption. Hence, Ind AS is primarily based on the IFRS issued by the International Accounting
Standards Board (IASB). However, there are certain carve-outs from the IFRS. There are also certain general differences between Ind AS and IFRS:

- The transitional provisions given in each of the standards under IFRS have not been given in Ind AS, since all transitional provisions related to Ind AS, wherever considered appropriate, have been included in Ind AS101, 'First-time adoption of Indian Accounting Standards', corresponding to IFRS 1, 'First-time adoption of International Financial Reporting Standards'.

- Different terminology is used in Ind AS when compared to IFRS, e.g. the term 'balance sheet' is used instead of statement of financial position' and 'statement of profit and loss' is used instead of 'statement of comprehensive income'.

Ind AS shall apply to both standalone and consolidated financial statements, except that the overseas subsidiaries, associates, joint ventures and other similar entities of an Indian company may prepare their standalone financial statements in accordance with the local requirements. Companies falling within the thresholds above (including their holding, subsidiary, joint venture or associate companies) shall not be required to prepare financial statements as per the Companies (Accounting Standards) Rules, 2006.

In line with the IFRS requirements, companies shall be required to prepare their first set of financial statements in accordance with the Ind AS effective at the end of its first Ind AS reporting period. Application of Ind AS is irrevocable, even if an entity, which has adopted Ind AS, does not fall under the thresholds for applicability of Ind AS in any subsequent year. It may be noted that Indian companies shall apply the new accounting standards on financial instruments (Ind AS 109) and revenue from contracts with customers (Ind AS 115) ahead of the timelines set for their peers globally. As per IASB IFRS, the date for the applicability of IFRS 9 and IFRS 15 is the year beginning 1 January 2018.Ind AS 
has a specific standard on transition to the new financial reporting framework (Ind AS 101). It provides certain optional exemptions and mandatory exceptions to entities for ensuring a smooth transition from existing accounting practices. It is important that accounting professionals and CFOs make informed accounting policy choices that will be available upon transition. The dynamic business landscape and growing business complexities pose significant challenges in converging to the changing financial reporting framework for Indian corporate. The drivers of these challenges are diverse, interalia:

- Accounting policy choices available under the transition standard

- Increasing size and complexity of business transactions

- Increasing pressure to publish financial information quickly

\begin{tabular}{|c|c|c|c|}
\hline $\begin{array}{l}\text { Sr. } \\
\text { no }\end{array}$ & Area & $\begin{array}{l}\text { Ind-AS (Indian Accounting } \\
\text { Standards as converged with IFRS) }\end{array}$ & Indian Accounting Standards \\
\hline 1 & Substance & $\begin{array}{l}\text { Ind-AS are generally substance based. } \\
\text { For example, consolidation is required } \\
\text { under Ind-AS } 110 \text { if the } \\
\text { holding company has control over its } \\
\text { subsidiary and definition of control is } \\
\text { substance based. Research an }\end{array}$ & $\begin{array}{l}\text { Indian Accounting Standards ('AS') are } \\
\text { generally rule based and are less flexible. } \\
\text { For example as per AS } 21 \text {, consolidation } \\
\text { is required if a company holds more than } \\
50 \% \text { of the voting rights or control in the } \\
\text { board of directors }\end{array}$ \\
\hline 2 & Applicability & $\begin{array}{l}\text { Ind-AS will be applicable in phases to } \\
\text { mainly large companies (see table } \\
\text { given above in this article) } 2456=647\end{array}$ & $\begin{array}{l}\text { AS applicable to not only the companies, } \\
\text { but to other entities as well. To the } \\
\text { companies, notified standards } \\
\text { under company rules are applicable and } \\
\text { for other entities, AS published by ICAI } \\
\text { are applicable }\end{array}$ \\
\hline 3 & Guidance & $\begin{array}{l}\text { Ind-AS generally use the word - } \\
\text { "shall" in its guidance, which makes it } \\
\text { more strict. }\end{array}$ & $\begin{array}{l}\text { AS generally use the word "Should" } \\
\text { which is more advisory in nature }\end{array}$ \\
\hline 4 & New Standards & $\begin{array}{l}\text { Ind-AS provide guidance on various } \\
\text { transactions like agriculture, business } \\
\text { combinations etc. }\end{array}$ & These guidance were not existing in AS. \\
\hline 5 & Interpretations & $\begin{array}{l}\text { Ind-AS has incorporated various } \\
\text { interpretations which are part of IFRS, } \\
\text { thus making it comprehensive }\end{array}$ & $\begin{array}{l}\text { Various guidance notes and other } \\
\text { publications are available along with AS } \\
\text { in existing scenario }\end{array}$ \\
\hline 6 & $\begin{array}{l}\text { Conceptual } \\
\text { Differences }\end{array}$ & $\begin{array}{l}\text { There are specific guidances on } \\
\text { various matters like depreciation or } \\
\text { revenue recognition }\end{array}$ & $\begin{array}{l}\text { AS contains subjectivity at quite a few } \\
\text { places. }\end{array}$ \\
\hline
\end{tabular}

- Continuously evolving accounting standards, guidance and references

- Multiplicity of accounting practices and standards across subsidiaries and segments

- Quality of accountants available for data processing and validation

- Accordingly, it is imperative for a company to define a process whereby the following is achieved:

- Choice of appropriate accounting policies and consistency in application thereof, across subsidiaries, segments, jurisdictions and sectors

- Well-defined systems for timely and accurate financial reporting

- Reliance on processes rather than on people

- Difference between Ind-AS and Indian Accounting Standards: 
The transition will have a considerable impact on the computation of revenue, operating profit, net profit, and networth of the listed companies. Sectors including metals, telecoms, oil \& gas, and real estate are likely to be impacted most. According to analyst estimates, the new norms will increase revenues by 4 $5 \%$, while overall EBITDA may drop by $2-3 \%$. SEBI had given publicly-listed companies additional one month to declare results for the June and the September quarters to comply with the new norms.

Every country stipulates a method for companies to report financial data based on rules called accounting standards. India has so far followed Indian Generally Acceptable Accounting Principle (IGAAP). However, from FY17, it will follow Ind-AS whose principles are closely based on international accounting system called IFRS. This will increase comparability of Indian companies with their international counterparts

\begin{tabular}{|c|c|c|}
\hline $\begin{array}{l}\text { Under existing } \\
\text { standard (IGAAP) }\end{array}$ & $\begin{array}{l}\text { New accounting } \\
\text { (Ind-AS) }\end{array}$ & Impact \\
\hline $\begin{array}{l}\text { Revenues } \\
\text { calculated net of } \\
\text { excise and dutles }\end{array}$ & $\begin{array}{l}\text { Revenues will be } \\
\text { calculated by adding } \\
\text { exclse duty }\end{array}$ & $\begin{array}{l}\text { Higher revenue, lower } \\
\text { margin and EPS neutral. } \\
\text { Consumer staples, auto, } \\
\text { capital goods, and ce- } \\
\text { ment companies will } \\
\text { be most Impacted }\end{array}$ \\
\hline $\begin{array}{l}\text { Most companies } \\
\text { having employee } \\
\text { stock option (ESOP) } \\
\text { based on Intrinsic } \\
\text { value }\end{array}$ & $\begin{array}{l}\text { Mandates ESOP cost } \\
\text { booked under falr } \\
\text { value accounting }\end{array}$ & $\begin{array}{l}\text { Likely to Increase } \\
\text { employee cost }\end{array}$ \\
\hline $\begin{array}{l}\text { Proposed dividend } \\
\text { is recognised in the } \\
\text { same year }\end{array}$ & $\begin{array}{l}\text { Proposed dividend } \\
\text { In a year when ap- } \\
\text { proved by sharehold- } \\
\text { ers }\end{array}$ & $\begin{array}{l}\text { Llkey to increase the year } \\
\text { end book value of the } \\
\text { company. This may lower } \\
\text { return on equity(RoE) } \\
\text { of high-dlvidend paying } \\
\text { companies }\end{array}$ \\
\hline $\begin{array}{l}\text { Under M\&A assets } \\
\text { are recognised at } \\
\text { book value }\end{array}$ & $\begin{array}{l}\text { Asset and liabilility to } \\
\text { be recognised at falr } \\
\text { value and continen- } \\
\text { tent llabilities to be } \\
\text { accounted at fair } \\
\text { value. Goodw III value } \\
\text { to be tested annually }\end{array}$ & $\begin{array}{l}\text { Companles } \\
\text { having high goodwill } \\
\text { in balance sheet will } \\
\text { see votillties in their } \\
\text { earnings }\end{array}$ \\
\hline $\begin{array}{l}\text { Current Investment } \\
\text { valued at cost or } \\
\text { market value }\end{array}$ & $\begin{array}{l}\text { Needs to be valued } \\
\text { at falr value }\end{array}$ & $\begin{array}{l}\text { Greater volatility In } \\
\text { other Income, cash-rich } \\
\text { companies will be more } \\
\text { Impacted }\end{array}$ \\
\hline $\begin{array}{l}\text { Redeemable prefer- } \\
\text { ence share treated } \\
\text { as part of equity }\end{array}$ & $\begin{array}{l}\text { Will be treated as If- } \\
\text { ability, preference div- } \\
\text { Idend will be treated } \\
\text { as interest cost }\end{array}$ & $\begin{array}{l}\text { Higher debt to equity } \\
\text { and lower EPS }\end{array}$ \\
\hline $\begin{array}{l}\text { Major repalr } \\
\text { charged as } \\
\text { expenses }\end{array}$ & $\begin{array}{l}\text { Allowed to } \\
\text { capltallsed }\end{array}$ & $\begin{array}{l}\text { Could lead to } \\
\text { lower EPS }\end{array}$ \\
\hline
\end{tabular}

The new accounting standards recognize substance over form and importance of the fair value to compute financial statements. This means accurate reporting will gain importance over just complying with legal provisions and it should reflect the most current picture of financials.

It will impact how key financials such as revenue, operating profit, net profit, book value, goodwill, and return on equity will be computed. For instance, under the existing rules, sales are calculated after deducting excise duty. Under the new norms, excise duty will be treated as a tax on manufacturing activity. Hence, it should be a part of revenue. This will increase the revenue of companies, but depress operating margin. However, EPS will remain unchanged. The challenge of Ind AS conversion projects will usually be very significant, as the differences between Indian GAAP and Ind AS are many. With many stakeholders involved, and given the combination of marketing, financial reporting, human resources, IT, process, controls, tax and risk management issues, change needs to be managed.

There are major demands on financial and human resources in companies. An Ind AS conversion project cannot be a distraction from the primary activities of the business. It must be integrated, coordinated, and aligned.

\section{REFERENCES:}

1. www.thehindubusinessline.com

2. www.pwc.in

3. www.ey.com

4. www2.deloitte.com

5. www.pwc.in/assets/pdfs/publications/2016/pwcind-as-impact-analysis.pdf

6. https://www.pwc.in/assets/pdfs/publications/.../pw c-ind-as-outlook-survey-report.pdf

7. https://www.mca.gov.in/Ministry/pdf/Ind_AS1.pd $\mathrm{f}$

8. www.cakart.in/blog/differences-between-ind-asand-existing-as

9. https://economictimes.indiatimes.com 